\title{
The bacteriology of infected malignant ulcers
}

\author{
VO ROTIMI, ${ }^{*}$ FA DUROSINMI-ETTI $\dagger$ \\ From the Departments of $*$ Microbiology and $\dagger$ Radiotherapy, College of Medicine, Lagos University Teaching \\ Hospital, P.MB 12003, Lagos, Nigeria
}

SUMMARY Infected ulcerated malignant tumours are often foul smelling and covered with necrotic tissue. We have studied 70 patients with infected ulcers; 30 of the underlying lesions in these patients were carcinoma of the breast, and 19 were a variety of skin cancers. Anaerobes were the predominant organisms isolated from individual ulcers. Of the 179 anaerobes isolated, 37 were Bacteroides asaccharolyticus, 31 each were $B$ melaninogenicus and anaerobic streptococci, $29 B$ fragilis, and $17 \mathrm{~B}$ ureolyticus. Among the facultative organisms Escherichia coli was the commonest and was isolated mainly from patients with carcinoma of the breast. Most infections were mixed, yielding both anaerobes and aerobes and this made interpretation of the role of individual pathogens difficult to assess.

Infected ulcers superimposed on malignant lesions are usually characterised by dirty greyish necrotic sloughs, inflammed margins, and very offensive odour. A number of studies on the role of anaerobes in the aetiology of these infections have provided, indirectly through antibiotic trials, an insight into the type of bacteria that may be present in these lesions. ${ }^{1-6}$

Although anaerobes together with some facultative bacteria can be isolated from these infected ulcers, it is doubtful whether their presence often leads to bacteraemia and subsequent septicaemia. ${ }^{78}$ However, the isolation of Bacteroides spp from blood culture, as an initial finding, may be indicative of some deep malignant lesions, particulary carcinoma of the colon.' As far as we know detailed studies on the bacteriology of infected ulcers superimposed on peripheral malignant lesions have not been reported. In order to provide base line data, we have studied bacteriologically all patients with infected ulcers with underlying malignant lesions admitted to the radiotherapy ward of the hospital.

\section{Material and methods}

\section{SPECIMENS}

Specimens were obtained from infected ulcers in 70 consecutive patients admitted to the radiotherapy ward for management of malignant lesions which had become secondarily infected and eroded.
Albumin coated cotton wool swabs (Exogen Ltd, Dumbarton Road, Glasgow) were used to obtain wound swabs. They were then broken into Amies transport medium and transported immediately to the anaerobe research laboratory of our hospital. Where feasible, pieces of debrided necrotic tissues were taken into sterile universal bottles and also into steamed cooked meat broth. All specimens were processed within $20 \mathrm{~min}$ of taking by a carefully controlled procedure. A set of blood cultures was obtained from the antecubital vein from all patients within the first $24 \mathrm{~h}$ of admission.

\section{CULTURE}

All specimens were cultured for anaerobic and aerobic organisms using standard laboratory methods. A set of freshly prepared and prereduced selective and non-selective media was used for isolation of the anaerobes: these included cooked meat broth, blood agar (Oxoid), blood agar plus neomycin $(100 \mu \mathrm{g} / \mathrm{ml})$; and BM agar made selective by the addition of kanamycin $(75 \mu \mathrm{g} / \mathrm{ml})$ and $2.5 \mu \mathrm{g} / \mathrm{ml}$ vancomycin. ${ }^{10}$ For the isolation of aerobes the following media were used: blood agar (Oxoid), MacConkey agar (Oxoid), Mannitol-salt agar (Oxoid), and crystal violet blood agar. Media used for blood culture were those routinely used in our clinical bacteriology laboratory-that is, brain heart infusion broth (Oxoid) and thioglycollate broth (Oxoid).

INCUBATION

The aerobic plates were incubated in air plus $10 \%$ $\mathrm{CO}_{2}$ at $37^{\circ} \mathrm{C}$ for $24 \mathrm{~h}$ initially and then $48 \mathrm{~h}$ when 
Table 1 Characteristic features of the cancer patients with infected ulcers

\begin{tabular}{|c|c|c|c|c|c|c|c|c|c|c|}
\hline \multicolumn{6}{|c|}{ General features of patients } & \multicolumn{5}{|c|}{ No of patients with the following clinical features } \\
\hline $\begin{array}{l}\text { Site of } \\
\text { ulcer }\end{array}$ & $\begin{array}{l}\text { Underlying } \\
\text { lesion }\end{array}$ & $\begin{array}{l}\text { No of } \\
\text { patients }\end{array}$ & $\begin{array}{l}\text { Mean age } \\
(y r)\end{array}$ & $\begin{array}{l}\text { No of } \\
\text { females }\end{array}$ & $\begin{array}{l}\text { No of } \\
\text { males }\end{array}$ & $\begin{array}{l}\text { Foul smelling } \\
\text { ulcers }\end{array}$ & $\begin{array}{l}\text { Normal body } \\
\text { temperature }\end{array}$ & $\begin{array}{l}\text { Temperature } \\
\text { of } \geqslant 38^{\circ} \mathrm{C}\end{array}$ & $\begin{array}{l}\text { Leukocytosis } \\
(\geqslant 9000)\end{array}$ & Bacteraemia \\
\hline \multirow{4}{*}{$\begin{array}{l}\text { Breast } \\
\text { Skin }\end{array}$} & \multirow{4}{*}{$\begin{array}{l}\text { Carcinoma } \\
\text { Malignant } \\
\text { melanoma } \\
\text { Sarcomas } \\
\text { Rodent ulcers }\end{array}$} & 30 & $43 \cdot 5$ & 30 & 0 & 30 & 23 & 7 & 2 & 1 \\
\hline & & 3 & 40.5 & 1 & 2 & 3 & 3 & 0 & 0 & $\mathbf{0}$ \\
\hline & & 12 & $61 \cdot 7$ & 3 & 9 & 11 & 11 & 1 & 0 & 0 \\
\hline & & 4 & $40 \cdot 5$ & 1 & 3 & 4 & 4 & $\mathbf{0}$ & $\mathbf{0}$ & $\mathbf{0}$ \\
\hline \multirow{3}{*}{$\begin{array}{l}\text { External } \\
\text { genitalia }\end{array}$} & Ca penis & 1 & 60 & 0 & 1 & 0 & 1 & 0 & $\mathbf{0}$ & $\mathbf{0}$ \\
\hline & Ca cervix & 5 & 50.5 & 5 & 0 & 5 & 4 & 1 & 0 & $\mathbf{0}$ \\
\hline & Ca vulva & 2 & $30 \cdot 0$ & 2 & 0 & 2 & 1 & 0 & 0 & 0 \\
\hline Axilla & Carcinoma & 4 & 40.7 & 2 & 2 & 2 & 4 & $\mathbf{0}$ & 0 & 0 \\
\hline Antrum. & Carcinoma & 1 & 30 & 0 & 1 & 1 & 1 & 0 & 0 & 0 \\
\hline Oral cavity & Ca tongue & 1 & 17 & $\mathbf{0}$ & 1 & 1 & 1 & 0 & 0 & 0 \\
\hline Eye & Retinoblastoma & a 4 & $9 \cdot 5$ & 1 & 3 & 3 & 2 & 2 & 1 & 0 \\
\hline Mandible & Carcinoma & 3 & $36 \cdot 5$ & 0 & 3 & 3 & 3 & 0 & 0 & 0 \\
\hline
\end{tabular}

$\mathrm{Ca}=$ carcinoma .

necessary. The anaerobic plates were incubated anaerobically in the presence of $90 \% \mathrm{H}_{2}$ and $10 \%$ $\mathrm{CO}_{2}$ generated by Gas pak (Oxoid) using the gas generating kit system and anaeobic jars, each equipped with one satchet of $4 \mathrm{~g}$ room temperature catalysts (Oxoid Ltd, Basingstoke, England). The jars were controlled biologically using Simmon citrate agar slope seeded with Pseudomonas aeruginosa and incubated at $37^{\circ} \mathrm{C}$ for $48 \mathrm{~h}$ and extended for $72 \mathrm{~h}$ if necessary. The blood culture bottles were incubated in air at $37^{\circ} \mathrm{C}$ for $24 \mathrm{~h}$, subcultured, and incubation was then continued for up to seven days with daily inspection.

\section{IDENTIFICATION}

All the aerobic micro-organisms isolated were identified by the methods of Cowan" and API ${ }_{20}$ system (API System, SA, La Balme Les Grottes, Montalier, Vercieu, France). Representative colonies of the anaerobes were Gram stained and subcultured on to fresh blood agar and BM agar with kanamycin and vancomycin on which metronidazole $(5 \mu \mathrm{g})$

Table 2 Isolation rate of anaerobes and aerobes from all patients

\begin{tabular}{|c|c|c|c|}
\hline $\begin{array}{l}\text { Species of } \\
\text { anaerobes }\end{array}$ & $\begin{array}{l}\text { No of } \\
\text { isolates }\end{array}$ & $\begin{array}{l}\text { Species of } \\
\text { aerobes }\end{array}$ & $\begin{array}{l}\text { No of } \\
\text { isolates }\end{array}$ \\
\hline $\begin{array}{l}\text { All anaerobes } \\
B \text { melaninogenicus } \\
\quad \text { ss melaninogenicus } \\
\text { ss intermedius } \\
B \text { asaccharolyticus } \\
B \text { ureolyticus } \\
B \text { fragilis } \\
B \text { thetaiotaomicron } \\
B \text { ovatus } \\
B \text { bivius } \\
\text { Anaerobic streptococci } \\
\text { Eubacterium spp } \\
\text { Fusobacterium } \\
\text { necrophorum } \\
\text { Bacteroides spp }\end{array}$ & $\begin{array}{r}179 \\
10 \\
21 \\
37 \\
17 \\
29 \\
7 \\
6 \\
4 \\
31 \\
8 \\
2 \\
7\end{array}$ & $\begin{array}{l}\text { All aerobes } \\
\text { E coli } \\
\text { Klebsiella spp } \\
\text { Pr mirabilis } \\
\text { Pr morganii } \\
\text { Ps aeruginosa } \\
\text { Ps fuorescens } \\
\text { Acinetobacterium spp } \\
\text { Enterobacterium spp } \\
\text { Group A streptococci } \\
\text { Group G streptococci } \\
\text { Staph aureus } \\
\text { Staph albus } \\
\text { Str faecalis }\end{array}$ & $\begin{array}{r}103 \\
21 \\
3 \\
14 \\
5 \\
8 \\
2 \\
3 \\
5 \\
6 \\
2 \\
18 \\
13 \\
3\end{array}$ \\
\hline
\end{tabular}

discs were placed. They were identified by initial sensitivity to the metronidazole disc and confirmed and speciated by methods already described..$^{12} 13$ All isolates were quantified by a semi-quantitative method previously described..$^{14}$

\section{Results}

A total of 70 swabs or necrotic tissue specimens obtained from 70 patients were cultured; each patient provided a single specimen. Seventy blood cultures were also investigated.

The general features and clinical characteristics of the patients are summarised in Table 1. All infected ulcers were peripheral, and the underlying lesions were as follows: cancer of the breast $(30 / 70)$, skin cancers (19/70), cancer of the external genitalia, including exocervix (8), and a miscellaneous group of cancers-axilla (4), eye (4), mandible (3), mouth (1), and antrum (1). Sixty five $(92 \cdot 8 \%)$ of the 70 infected ulcers were foul smelling. The body temperature was normal $\left(37.5^{\circ} \mathrm{C}\right)$ in $58(82.9 \%)$ of the 70 patients while a temperature of $\geqslant 38^{\circ} \mathrm{C}$ was recorded in the remaining 12 patients. Only three patients had a leucocytosis. All but one of the blood cultures were negative and that grew Staphylococcus aureus.

The micro-organisms, anaerobes and aerobesisolated from the infected ulcers are shown in Table 2. Anaerobes were the predominant microorganisms, with a mean score of $4^{+}$on a scale of $1^{+}-5^{+}$estimated by the semi-quantitative method, while the aerobic micro-organisms had a mean score of $3^{+}$on the same scale. Of a total of 282 bacterial isolates, anaerobic micro-organisms accounted for $179(63 \cdot 3 \%)$.

The commonest anaerobe was Bacteroides asaccharolyticus, which made up $21 \%$ of the 179 anaerobes and $13 \%$ of the total 282 isolates. 
Table 3 Isolation of anaerobes and aerobes from infected ulcers of patients with cancer

\begin{tabular}{|c|c|c|c|c|c|c|c|c|}
\hline \multirow[t]{2}{*}{ Micro-organisms isolated } & \multicolumn{8}{|c|}{ No of isolates from infected ulcers in the following sites } \\
\hline & $\begin{array}{l}\text { Breast } \\
(n=30)\end{array}$ & $\underset{(n=19)}{S k i n}$ & $\begin{array}{l}\text { External } \\
\text { genitals } \\
(n=8)\end{array}$ & $\begin{array}{l}\text { Eye } \\
(n=4)\end{array}$ & $\begin{array}{l}\text { Antrum } \\
(n=I)\end{array}$ & $\begin{array}{l}\text { Axilla } \\
(n=4)\end{array}$ & $\begin{array}{l}\text { Mouth } \\
(n=1)\end{array}$ & $\begin{array}{l}\text { Mandible } \\
(n=3)\end{array}$ \\
\hline $\begin{array}{l}\text { B fragilis } \\
\text { B asaccharolyticus } \\
B \text { melaninogenicus* } \\
\text { B ureolyticus } \\
\text { Anaerobic streptococci } \\
\text { B thetaiotaomicron } \\
B \text { ovatus } \\
\text { Bacteroides spp } \\
\text { Eubacterium spp } \\
\text { Fusobacterium spp } \\
\text { B bivius } \\
\text { E coli } \\
\text { Pseudomonas aeruginosa } \\
\text { Proteus spp } \\
\text { Staph aureus } \\
\text { Staph albus } \\
\text { Group A streptococci } \\
\text { Group G streptococci } \\
\text { Ps fuorescens } \\
\text { Kleb aerogenes } \\
\text { Acinetobacter spp } \\
\text { Enterobacterium spp } \\
\text { Str faecalis }\end{array}$ & $\begin{array}{r}12 \\
23 \\
19 \\
13 \\
16 \\
7 \\
6 \\
7 \\
8 \\
0 \\
0 \\
11 \\
7 \\
9 \\
5 \\
7 \\
5 \\
2 \\
2 \\
3 \\
2 \\
4 \\
0\end{array}$ & $\begin{array}{r}9 \\
11 \\
6 \\
1 \\
9 \\
0 \\
0 \\
0 \\
0 \\
0 \\
0 \\
4 \\
3 \\
8 \\
5 \\
6 \\
1 \\
0 \\
0 \\
0 \\
1 \\
1 \\
0\end{array}$ & $\begin{array}{l}5 \\
0 \\
4 \\
0 \\
3 \\
0 \\
0 \\
0 \\
0 \\
0 \\
4 \\
1 \\
0 \\
1 \\
3 \\
0 \\
0 \\
0 \\
0 \\
0 \\
0 \\
0 \\
3\end{array}$ & $\begin{array}{l}3 \\
0 \\
0 \\
0 \\
2 \\
0 \\
0 \\
0 \\
0 \\
0 \\
0 \\
0 \\
0 \\
0 \\
2 \\
0 \\
0 \\
0 \\
0 \\
0 \\
0 \\
0 \\
0\end{array}$ & $\begin{array}{l}0 \\
0 \\
0 \\
1 \\
0 \\
0 \\
0 \\
0 \\
0 \\
0 \\
0 \\
0 \\
0 \\
0 \\
1 \\
0 \\
0 \\
0 \\
0 \\
0 \\
0 \\
0 \\
0\end{array}$ & $\begin{array}{l}0 \\
0 \\
0 \\
2 \\
1 \\
0 \\
0 \\
0 \\
0 \\
0 \\
0 \\
2 \\
0 \\
1 \\
0 \\
0 \\
0 \\
0 \\
0 \\
0 \\
0 \\
0 \\
0\end{array}$ & $\begin{array}{l}0 \\
0 \\
1 \\
0 \\
0 \\
0 \\
0 \\
0 \\
0 \\
1 \\
0 \\
0 \\
0 \\
0 \\
0 \\
0 \\
0 \\
0 \\
0 \\
0 \\
0 \\
0 \\
0\end{array}$ & $\begin{array}{l}0 \\
3 \\
1 \\
1 \\
0 \\
0 \\
0 \\
0 \\
0 \\
2 \\
0 \\
0 \\
0 \\
0 \\
2 \\
0 \\
0 \\
0 \\
0 \\
0 \\
0 \\
0 \\
0\end{array}$ \\
\hline
\end{tabular}

${ }^{*} B$ melaninogenicus ss melaninogenicus and ss intermedius.

Anaerobic streptococci, $B$ melaninogenicus, $B$ fragilis, and $B$ ureolyticus were also common.

Escherichia coli was the most frequent facultative micro-organism, accounting for $20.4 \%$ of the 103 aerobic bacteria isolated and $7.5 \%$ of the 282 total isolates. Proteus spp and Staph aureus were frequently isolated.

Table 3 details the distribution of bacterial isolates from infected ulcers associated with particular sites.

\section{Discussion}

The results of this study demonstrate the complex bacterial population isolated from infected ulcers superimposed on malignant lesions. These localised infections, although not associated with bacteraemia in this study, represent an interesting model for understanding anaerobic infections. Anaerobes were isolated from all the foul smelling infected ulcers. Most of these anaerobes were black pigmented $B$ asaccharolyticus and $B$ melaninogenicus, $B$ fragilis, $B$ ureolyticus, as well as anaerobic streptococci, all of which are known opportunistic pathogens. ${ }^{15-17}$ When anaerobes were found in the relatively odourless ulcers they were usually either anaerobic streptococci alone or in combination with $B$ ureolyticus.

Mixed anaerobes were present in about $87 \%$ of the 70 patients in the present study. The commonest combination was $B$ asaccharolyticus, $B$ melaninogenicus, anaerobic streptococci and/or $B$ fragilis, and a facultative bacteria. This combination was commonly seen in patients with cancer of the breast or skin. $B$ fragilis, anaerobic streptococci, and $B$ ureolyticus was the next most common combination.

The finding of facultative organisms, particularly Gram negative bacilli, in association with anaerobes in most of these infections makes the precise role of the anaerobes in ulcers difficult to assess, especially when concurrent associated bacteraemia could not be shown. Most reports presented by other workers on a series of related studies accord well with this observation. $^{578}$ Investigations by Finegold, 9 McHenry et al,,$^{18}$ and Finegold $e t$ al ${ }^{19}$ have, however, emphasised the importance of bacteroides bacteraemia as a potentially life threatening condition in patients with cancer. Because these patients are already severely compromised by their advanced lesions, anaerobic bacteraemia may easily develop, especially if any form of surgery is undertaken.

Anaerobic infections in malignant ulcers may represent a specific infective syndrome, like Melleney's synergistic gangrene or necrotising ulcerative gingivitis, from which anaerobes and aerobes can be isolated to the exclusion of anaerobic bacteraemia. Treatment of these types of infection with specific or broadspectrum antianaerobic agents is justified and there have been good clinical responses to these antibiotics in a number of controlled clinical trials already conducted on patients with cancer. ${ }^{1-6}$ The 
results of this study may be useful to our clinical colleagues, many of whom have at present no alternative to empirical antibiotic treatment, lacking adequate bacteriological base line data.

This study was supported by the College of Medicine of University of Lagos research grant, which is gratefully acknowledged. We thank Mrs M Cole for typing the manuscript.

\section{References}

' Klasterky J, Husson M, Weerts-Ruhl D, Daneau D. Anaerobic wound infection in cancer patients: comparative trials of clindamycin, tinidazole and doxycycline. Antimicrobiol Agents Chemother 1977;12:563-70.

${ }^{2}$ Ashby EC, Rees M, Dowding CH. Prophylaxis against systemic infection after transrectal biopsy for suspected prostatic carcinoma. Br Med J 1978;ii:1263-4.

${ }^{3}$ Klasterky J, Coppens L, Mombelti G. Anaerobic infections in cancer patients: comparative evaluations of clindamycin and cefoxitin. Antimicrobiol Agents Chemother 1979;16:366-71.

${ }^{4}$ Lagast H, Klasterky J. Anaerobic infections in cancer patients. Comparative trials of clindamycin, tinidazole, doxycycline cefoxitin and moxalactam. Infection 1982;10:144-8.

${ }^{5}$ Lagast H, Meunier-Carpenter F, Klasterky J. Moxalactam treatment of anaerobic infections in cancer patients. Antimicrobial Agents Chemother 1982;22:604-10.

${ }^{6}$ Durosinmi-Etti FA, Rotimi VO. The use of topical metronidazole (flagyl) powder in the treatment of neoplastic ulcers. Niger Med $J$ (in press).

' Sinkovits JG, Smith JP. Septicaemia with Bacteroides in patients with malignant disease. Cancer 1970;25:663-71.

${ }^{8}$ Felner JM, Dowell VR. Bacteroides bacteraemia. Am J Med 1971;50:787-96.
${ }^{9}$ Finegold SM. Anaerobic bacteria in human disease. New York: Academic Press, 1977:182-201.

${ }^{10}$ Holbrook WP, Ogston SA, Ross PW. A method for the isolation of Bacteroides melaninogenicus from the human mouth. $J$ Med Microbiol 1978;11:203-7.

"Cowan ST. Manual for the identification of medical bacteria. 2nd ed. Cambridge: Cambridge University Press, 1974.

12 Duerden BI, Collee JG, Brown R, Deacon AE, Holbrook WP. A scheme for the identification of clinical isolates of gramnegative anaerobic bacilli by conventional tests. J Med Microbiol 1980;13:231-45.

${ }^{13}$ Rotimi VO, Faulkner J, Duerden BI. Rapid methods for the identification of gram-negative anaerobic bacilli. Med Lab Sci 1980;37:331-9.

${ }^{14}$ Rotimi VO, Duerden BI. The development of the bacterial flora in normal neonates. $J$ Med Microbiol 1981;14:51-62.

${ }^{15}$ Holland JW, Hill EO, Altemeier WA. Numbers and types of anaerobic bacteria isolated from clinical specimens since 1960 . $J$ Clin Microbiol 1977;5:20-5.

${ }^{16}$ Duerden BI. The identification of gram-negative anaerobic bacilli from clinical specimens. J Hyg (Camb) 1980;84:30113.

${ }^{17}$ Duerden BI, Bennet KW, Faulkner J. Isolation of Bacteroides ureolyticus from clinical infections. J Clin Pathol 1982; 35:309-12.

${ }^{18}$ McHenry MC, Wellman WE, Martin WJ. Bacteraemia due to Bacteroides. Arch Intern Med 1961;107:572-7.

${ }^{19}$ Finegold SM, Marsh VH, Bartlett JG. Anaerobic infections in the compromised host. In: Proceedings of International conference on nosocomial infections. Baltimore: Waverly Press, 1971:265-79.

Requests for reprints to: Dr VO Rotimi, Department of Microbiology, College of Medicine, University of Lagos, PMB 12003, Lagos, Nigeria. 